alternative compensation scheme for disadvantaged dispensing doctors:

- No alternative scheme

- A compensation scheme funded by dispensing doctors for the benefit of their disadvantaged colleagues

- An insurance based scheme to provide a loss of earnings policy

- A compensation scheme funded by the whole profession

- A special cases compensation panel to consider cases of special hardship.

Michael Wilson hoped that the GMSC would make it clear that the pharmacists had renegued on a deal made 12 years before and not the GMSC. Unless the committee found a solution Dr Mac Armstrong feared that the Dispensing Doctors Association would retort that the BMA did not care about dispensing doctors. The GMSC had always maintained that the loss of dispensing income would affect patient care - a centrally funded scheme was essential.

\section{GPs' revised cost limits}

The Department of Health has sent family health services authorities (FHSAs) revised cost limits under the cost rent and improvement grant schemes. The limits are being reduced to reflect an overall fall in building costs across the country. Regional variations in building costs have also been taken into account in revised relativities between the cost limit bands. The cost limits have been further adjusted to reflect fully the increase in the VAT rate from $15 \%$ to $171 \frac{1}{2} \%$. In order to give FHSAs and general practitioners notice of the change the cost limits in the statement of fees and allowances which apply to the period 1 April 1990 to 31 March 1991 will be extended to apply until the end of May 1991. The new cost limits will come into effect on 1 June 1991 and will apply until 31 March 1992.

\section{BMA film and video awards}

The chief medical officer, Sir Donald Acheson, presented awards to the winners of the BMA's 1991 film and video competition at a ceremony last week. There was a record 165 entries from pharmaceutical companies, television companies, independent producers, and university audiovisual departments.

Three gold awards went to:

- Quit and Win, a video from BBC Education aimed at helping people to stop smoking

- The Feminine Mistake, an American film which examines the reasons why young women start smoking and the effect of cigarette advertising

- Helping a Mother to BreastfeedNo Fine Investment, made by Healthcare Productions for the Royal College of Midwives. It aims to encourage more mothers to breast feed successfully by preparing mid- wives to show them the correct techniques.

\section{Part time training posts advertised}

Part time training posts have been advertised nationally for the first time. Up to 10 posts are available for doctors who live in the Northern region for registrar training in medicine, surgery, pathology, and psychiatry. Part time posts are not new but normally doctors have to apply to their regional health authority in the hope of getting a supernumerary post. The region wants to encourage people who have left full time medicine to return to work. Half of those entering medical school are now women but few of them reach senior positions. Although the region expects the posts to be of particular interest to women, the posts will be available to men. Further details may be obtained from the Northern Regional Health Authority's medical staffing section at Benfield Road, Newcastle upon Tyne NE4 6PY (tel: 091276 1505).

\section{Indemnity for GPs in hospitals}

The General Medical Services Committee is trying to clarify with the medical defence societies whether they would advise and defend general practitioners if an action arose while they were working in a hospital-in other words, act in the same way as they did before NHS indemnity was introduced. The societies are dis cussing the matter with the health departments, who are refusing to indemnify doctors who work under the bed fund. The societies have confirmed that they will help doctors to resolve disputes about legal liability, disputes which should be resolved by the defence societies and health authorities. The GMSC is advising general practitioners who work in the hospital and community health services that the case for indemnity cover from the health authority would be strengthened if they had contracts for services with a health authority.

\section{Overseeing health in Europe}

In the European Community health matters are formulated by several directorates general, and communication between them is not always effective (see box).

Pressed recently to say whether the European Commission intended to extend its role in determining health policy the commissioner for Directorate General V (employment, industrial relations, and social affairs) said that the commission was seeking a greater role in the areas of "prevention, care, and medical assistance." It was also possible that the commission might seek a revision of the Treaty of Rome so that certain

\section{European institutions}

\section{Council of Ministers}

The Council is the European Community's principal decision making body and most powerful institution. Each national government has a seat on it and for the subject under discussion each national government is represented by the government minister responsible for this area.

\section{European Commission}

The commission is the executive body of the community. It proposes and carries out policies and is responsible for monitoring the implementation of community legislation by member states.

\section{European Parliament}

The parliament does not have the legislative powers of a national government but its opinion must be sought on the vast majority of proposals. It is responsible for approving the budget of the commission.

health matters could be covered by a qualified majority vote in the Council of Ministers rather than as now, where there is no specific provision.

This is a far cry from a separate directorate general on health, but the BMA intends to ask the commissioner, Mrs Vasso Papandreou, to expand on her statement. At its recent meeting the BMA's European Communities committee also decided to consult on whether the BMA should support or lobby for a specific directorate general with responsibility for health issues.

Philip Evans, who represents the Royal College of General Practitioners on the European Communities committee, suggested that the forthcoming European Act might well lead to the Treaty of Rome being revised and he suggested that the medical profession should take part in the debate as early as possible. A separate directorate general might be advantageous, Michael Wilson believed. But he was worried that no one section of the Department of Health seemed to have overall responsibility for European medical affairs.

\section{Liability of suppliers of services: possible separate health directive}

There is a possibility that health care might be removed from the proposed European Community directive on the liability of suppliers of services and form the basis of a separate directive. The BMA's European Communities committee recently decided to seek an urgent meeting

\title{
Economic and Social
}

\section{Committee}

The committee is an advisory group, which, like the parliament, has to be consulted by the Council of Ministers and the commission and which also produces opinions on its own initiative.

\section{Directorates General}

The 17 commissioners have responsibility for a particular area of policy. The following directorates general produce policy which has some impact on medicine and health:

- Directorate General III: Internal market and industrial affairs

- Directorate General V: Employment, industrial relations, and social affairs

- Directorate General XI: Environment, consumer protection, and nuclear safety

- Directorate General XII: Science, research, and development

- Directorate General XIII: Telecommunication, information industries, and innovation.

with Paul Allen of the Department of Health's international division to discuss the subject.

There have been serious misgivings about the proposal in the European Communities committee, the BMA council's executive committee, and the Standing Committee of Doctors of the European Community because of the proposal to reverse the burden of proof. Doctors are worried that their relations with patients could be damaged and that there could be an increase in litigation with consequent financial implications.

The standing committee issued a strong statement at its recent meeting pointing out that the proposal could lead to defensive medicine and could deprive patients of progress in medical techniques. The work of doctors, it emphasised, could not be compared with that of people engaged in economic or industrial activity.

It was pointed out at the European Communities committee that separate directive dealing with health could be just as dangerous if it 